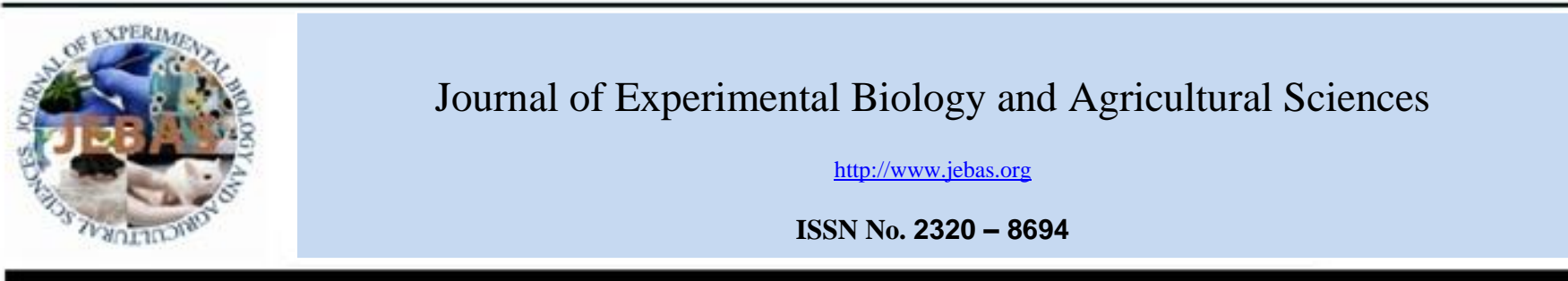

\title{
THE INFLUENCE OF SOIL-CLIMATIC CONDITIONS OF GROWTH ON THE CONTENT OF PHENOLIC COMPOUNDS IN TRIFOLIUM L. PLANTS
}

\author{
Alexander Loenidovich Mikhailov (D), Olga Arnoldovna Timofeeva (iD), \\ UlianaAleksandrovna Ogorodnova ${ }^{(\mathbb{D})}$, Nikita Sergeevich Stepanov
}

Department of Human Health, Institute of Fundamental Medicine and Biology, Kazan Federal University, Kazan, Russia

Received - September 25, 2020; Revision - November 16, 2020; Accepted - December 14, 2020

Available Online December 15, 2020

DOI: http://dx.doi.org/10.18006/2020.8(Spl-2-AABAS).S327.S335

\section{KEYWORDS}

Red Clover

White Clover

Biologically Active

Substances

Flavonoids

Isoflavonoids

Phenolic Compounds

\begin{abstract}
The current study was carried out to study the effect of growing conditions on the pharmaceutically promising biologically active phenolic compounds on the meadow clover plants. The impact of the plant development site on the contemplated mixes was additionally explored. The estimation of phenolic compounds in raw plant materials was carried out with the help of a spectrophotometer and photocolorimeter. Results of the study revealed that the place of plant growth conditions have remarkable effect on the content of the phenolic compounds. Further, the most ideal conditions available for clover plant growth and higher phenolic compounds were reported from the broad-leaved forests. Furthermore, the results also suggested that the most important elements which affecting the aggregation of phenolic compounds are soil nitrogen.
\end{abstract}

* Corresponding author

E-mail: almihailov@bk.ru (Alexander Loenidovich Mikhailov)

Peer review under responsibility of Journal of Experimental Biology and Agricultural Sciences.

Production and Hosting by Horizon Publisher India [HPI] (http://www.horizonpublisherindia.in/).

All rights reserved.
All the articles published by Journal of Experimental Biology and Agricultural Sciences are licensed under a Creative Commons Attribution-NonCommercial 4.0 International License Based on a work at www.jebas.org.

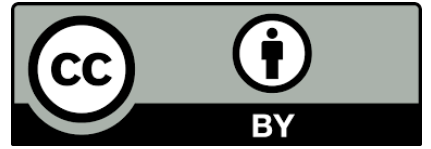




\section{Introduction}

The development of biologically active substances (BAS) in plants is a dynamic process and it is dependent on the plant ontogenesis and growing conditions (Jaakola \& Hohtola, 2010). Plants of the same species grown under various natural conditions have differences in the biosynthesis and collection of optional metabolites (Koricheva \& Barton, 2012). Among the reported metabolites, phenolic compounds, alkaloids, saponins, and terpenes are some common ones. Further, in reported secondary metabolites, phenolic mixes might be the biggest group of plant metabolites. They are broad in plants and contribute essentially to the shading, taste, and fragrance of numerous plant spices, nourishments and drinks. Some of the phenolic intensifies are pharmacologically important for their various medicinal properties. Huge numbers of the phenolic atoms are additionally viable cell reinforcements and free extreme scroungers, particularly flavonoids.

Clover (Trifolium) is a genus of the family Fabaceae that includes about 300 species. Red clover (Trifolium pratense L.) is a perennial or biennial herb with a well-developed tap root system with a large number of lateral and hypoctile adventitious roots. The leaves are tri compound, almost glabrous, the lower ones are long while the upper ones are short petioles. The leaflets of the lower leaves are obovate, the upper ones are oval or ovate, usually more pubescent below, the stipules are spurious, narrowed (Hoekstra et al., 2017). This plant has a long history of ethnomedicinal uses and various attempts have been taken to explore the phytochemical profile, physiological effects, and possible therapeutic action of various biochemicals (Kolodziejczyk-Czepas 2016). The objective of this study was to identify the effect of soil and climatic conditions on the accumulation of phenolic mixes in clover plants filling in the Republic of Tatarstan.

\section{Materials and Methods}

The aboveground parts of red clover were used as objects of study. The clover plant material was sampled from various "model" populations viz., deciduous forests (Kamsko-Ustinsky district, Verkhne-Uslonsky district, Apastovsky district, Tetyushsky district, Laishevsky district); coniferous-deciduous forests (Zelenodolsk district); southern taiga (Atninsky district); foreststeppe zone (Spassky district) of the districts of the Republic of Tatarstan:

The assay of phenolic compounds in raw plant material was carried out by spectrophotometry and photocolorimetry. Distilled water $(1.5 \mathrm{ml})$ was added to the $50 \mathrm{mg}$ raw material and boiled it 45 minutes in a water bath at a temperature of $70^{\circ} \mathrm{C}$. After this, the mixture was centrifuged at $15,000 \mathrm{rpm}$, and the resulted mixture was used for further study.
From the prepared aqueous extracts, $75 \mu \mathrm{l}$ of the aqueous extract was taken in the $1.5 \mathrm{ml}$ vial and $75 \mu \mathrm{l}$ of Folin-Denis reagent was added to it, and the mixture was stirred for three minutes, this was followed by the addition of $120 \mu \mathrm{NaCHO}_{3}$ solutions (10\%) and $1.2 \mathrm{ml}$ of water. The prepared mixture was left for 45 minutes and after this centrifuged at 16 thousand rpm for 2 minutes. Then, the optical density of the supernatant was determined at a wavelength of $725 \mathrm{~nm}$. For a control solution, $75 \mu \mathrm{l}$ of solvent was used instead of the extract. The total content of soluble phenolic compounds was calculated by using Sibgatullina (2011) formula:

\section{$\mathrm{C}=\mathrm{E} * \mathrm{~K} * \mathrm{R} * \mathrm{~V} / \mathrm{m} * 100$}

Where $C$ - the concentration of phenolic compounds ( $\mathrm{mg} / \mathrm{g}$ dry weight of the sample); $E$ - optical density at $725 \mathrm{~nm} ; R$ dilution, times; $V$ - volume of extract $(\mathrm{ml}) ; K$ - reference substance (epicatechin (480) conversion factor); and $m$-sample weight of plant material $(\mathrm{g})$.

The assay of flavonoids in terms of quercetin, avicularin, and cenaroside was conducted as follows: $1 \mathrm{~g}$ thin section of the raw material analytical sample was placed in a $150 \mathrm{ml}$ flask, this was followed by the addition of $30 \mathrm{ml}$ of $90 \%$ alcohol containing $1 \%$ concentrated hydrochloric acid, the flagon was associated with a reflux condenser and warmed on bubbling water shower for 30 min. The jar was then cooled to room temperature and sifted through a paper channel into a $100 \mathrm{ml}$ volumetric carafe. The extraction was rehashed again as mentioned above with $90 \%$ alcohol for $30 \mathrm{~min}$ and the filtrate was again diluted by adding 25 $\mathrm{ml}$ of $90 \%$ alcohol. From this solution, $2 \mathrm{ml}$ was taken out in a 25 $\mathrm{ml}$ volumetric flask and $1 \mathrm{ml}$ of $1 \%$ aluminum chloride solution prepared in $95 \%$ alcohol was added and the volume of the solution was diluted up to the mark with $95 \%$ alcohol (Klyshev et al., 1978). The content of the total flavonoids cynaroside, avicularin, and quercetin in absolutely dry raw materials was calculated in percent as per the given formula.

$$
\mathrm{X}=\frac{\mathrm{D} * 25 * 100 * 100 * 100}{764.6 * \mathrm{~m} * 2 *(100-\mathrm{W})}
$$

where D is the optical thickness of the test arrangement; 764.6 explicit retention file of the quercetin and aluminum chloride complex at $430 \mathrm{~nm} ; \mathrm{m}$ is the mass of crude materials in grams; $W$ is the mass misfortune on drying $(\%)$.

\section{Results and Discussion}

Previous researches have been well established that the concentration or amount of secondary metabolites is dependent on the response to stressful conditions, and these conditions enhanced the biosynthesis of secondary metabolites. Unfavorable environmental and climatic factors, including drought, changes in temperature, light intensity, lack of nutrients, and soil pollution, 
affect the physiological response of plants by stimulating the accumulation of secondary metabolites in medicinal plants (Król et al., 2014; Wang et al., 2015; Bautista et al., 2016). In response to stress factors of the external environment, plants have developed mechanisms of plant defense response to stress. Under the influence of stress factors, an imbalance arises between the formation of reactive oxygen species and their elimination. An excess of ROS launches a cascade of free-radical oxidative reactions, which often cause a disastrous effect on the entire plant organism.

Of the entire spectrum of these compounds synthesized by plants, the most sensitive to changes in environmental conditions are phenolic compounds, because they are weakly susceptible to catabolic transformations, and, therefore, retain information about the effect of stress on the plant organism for a longer time. Phenolic compounds are found in all plant organs, but their high concentration is especially found in actively functioning organs such as leaves, flowers, fruits, seeds, and they are also localized in integumentary tissues that perform protective functions. Further, the level of phenolic substances in the tissues and organs of the same plant species may vary with the different climatic conditions. Plants developing under pressure can biosynthesize more phenolic mixes than plants developing under ordinary conditions. These mixes have cell reinforcement properties and can use free extremists, which leads to a decrease in peroxidation of the cell membrane, therefore, they protect plant cells from oxidative stress (Shankar et al., 2009). The results of the current study determining the content of soluble phenolic compounds in samples of meadow clover tress samples collected from different growing zones during the different growing seasons, soil and climatic conditions (Figure 1 and 2). Further, the study revealed that plants collected from different environmental conditions have a different level of total phenolic content, which is fully confirmed by the literature data (Król et al., 2014; Bautista et al., 2016).

From the results of the current study, it is very clear that the highest soluble phenolic compounds were reported from the red clover plant collected from the zone of broad-leaved forests located in the Tetyushsky and Laishevsky districts. Further, plants sample collected from the Klyara river ( $7.92 \mathrm{mg} / \mathrm{g}$ dry weight) of Tetyushsky district, the village of Nikolskoye $(8.92 \mathrm{mg} / \mathrm{g}$ dry weight) and Nikolaevskoye (7.68 mg/g dry weight) of Laishevsky district also have high contents of total phenolic compounds (Figure 1). The least soluble phenolic compounds were reported from the red clover plant samples collected from the broad-leaved forests growing in the Apastovsky district while the minimum content was found in the samples collected from the village of Bolshie kokuzi (1.96 mg/g dry weight) (Figure 1). Results given in figure 2 shows that the content of soluble phenolic compounds in other

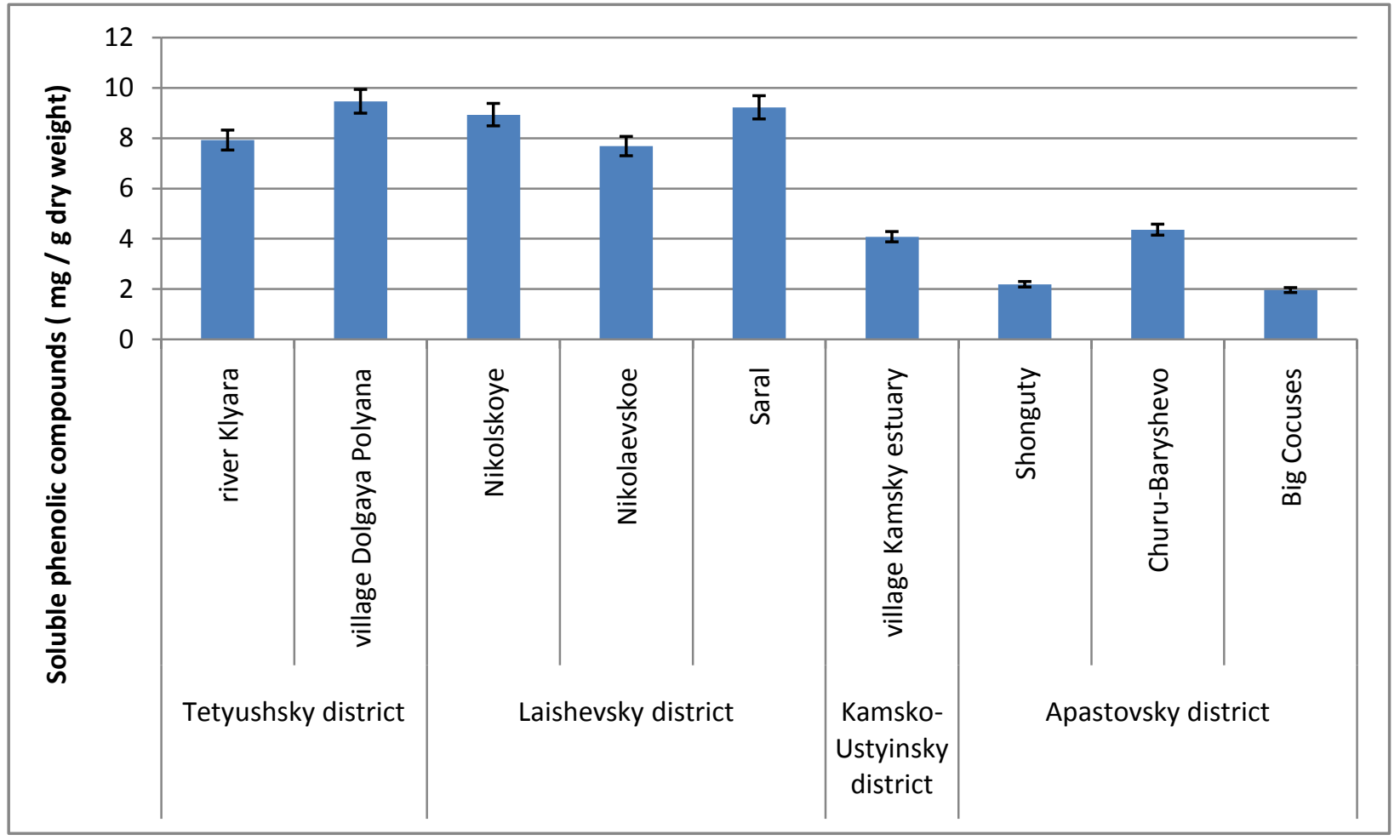

Figure 1The content of the total phenolic compounds in clover plants of the meadow zone of the broad-leaved forests of the Republic of Tatarstan 


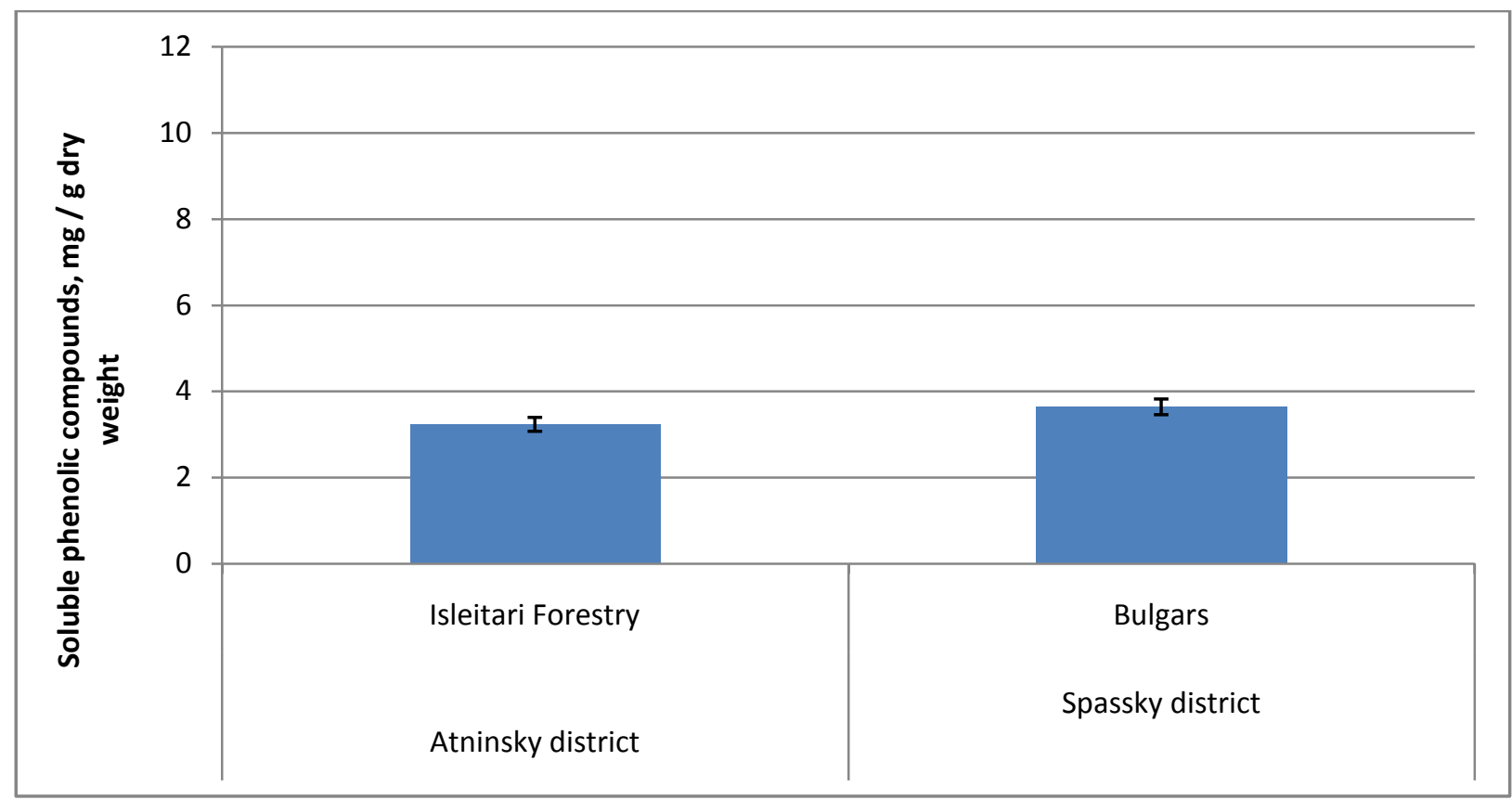

Figure 2 Difference in the clover plants phenolic compounds grown in different zones of growth of the Republic of Tatarstan

habitats of red clover has average values. Among all the studied districts, the least amount of phenolic compounds was found in clover from the Atninsky district (Isleitar forestry) of the southern taiga subzone.

Thus, from the results of study it can be concluded that the higher soluble phenolic compounds of meadow clover are the characteristic of the zone of broad-leaved forests of Tetyushsky and Laishevsky districts. This might be due to high illumination, dry to fresh soil moisture, low or sufficient supply nitrogen and slightly acidic or neutral reaction. And the least soluble phenolic compounds are found in meadow clover growing in the Atninsky district of the southern taiga zone (Figure 2), which could be due to the moderately warm climate, fresh periodically dry soils with high nitrogen content.

Among the reported phenolic compounds from the red clover, the most common phenolic compounds are flavonoids, which largely determine the value of this plant as a medicinal herb. Flavonoids have capillary-strengthening, antispasmodic, anti-stress, antitoxic, anti-atherosclerotic, immunomodulatory, anticarcinogenic, hepatoprotective, and other effects (Havsteen, 1983; Hertog et al., 1995). The accumulation of flavonoids by plants appears to be a defense mechanism against extensive oxidative damage to their photosynthetic apparatus under the influence of biotic factors. Consequently, the composition and quantitative content of flavonoids can show a wide range of values depending on the external conditions in different places of growth.
The results of flavonoids assays (cynaroside, avicularin, quercetin) in the meadow clover plants samples collected from ecologically different districts of the Republic of Tatarstan have been represented in Figures 3-8. The study found that plants collected from different environmental conditions are different in their flavonoid content. Further, among the reported flavonoids, the dominant one is cynaroside - a luteolin glycoside, which is a flavone. Representatives of flavonols - quercetin and arabinoside of quercetin - avicularin are reported in less quantity.

The most elevated substance cynaroside was reported in higher concentration from the red clover samples collected from the deciduous forests of Tetyushsky and Laishevsky districts. The maximum value of cynaroside was reported from the sample collected from the Klyara river (35.8\%) and the village of Dolgaya Polyana (27.03\%) of the Tetyushsky district (Figure 3). Further, high content of cynaroside was also reported from the red clover plant samples collected from the coniferous-broadleaved forests (20.03\%) and (21.67\%) in the Zelenodolsk district (Figure 4).

The least concentration of cynaroside was observed from the sample collected from Kamsko-Ustichny district (5.67\%), Apastovsky district (6.07-6.32\%), broad-leaved forests (Fig. 3), southern taiga (5.94\%) (Atninsky district), and forest-steppe (Spassky district) subzones (6.71\%) (Figure 4). Thus, the highest content of cynaroside was typically reported from the zone of deciduous forests of Tetyushsky and Laishevsky districts (Figure 3-4). 


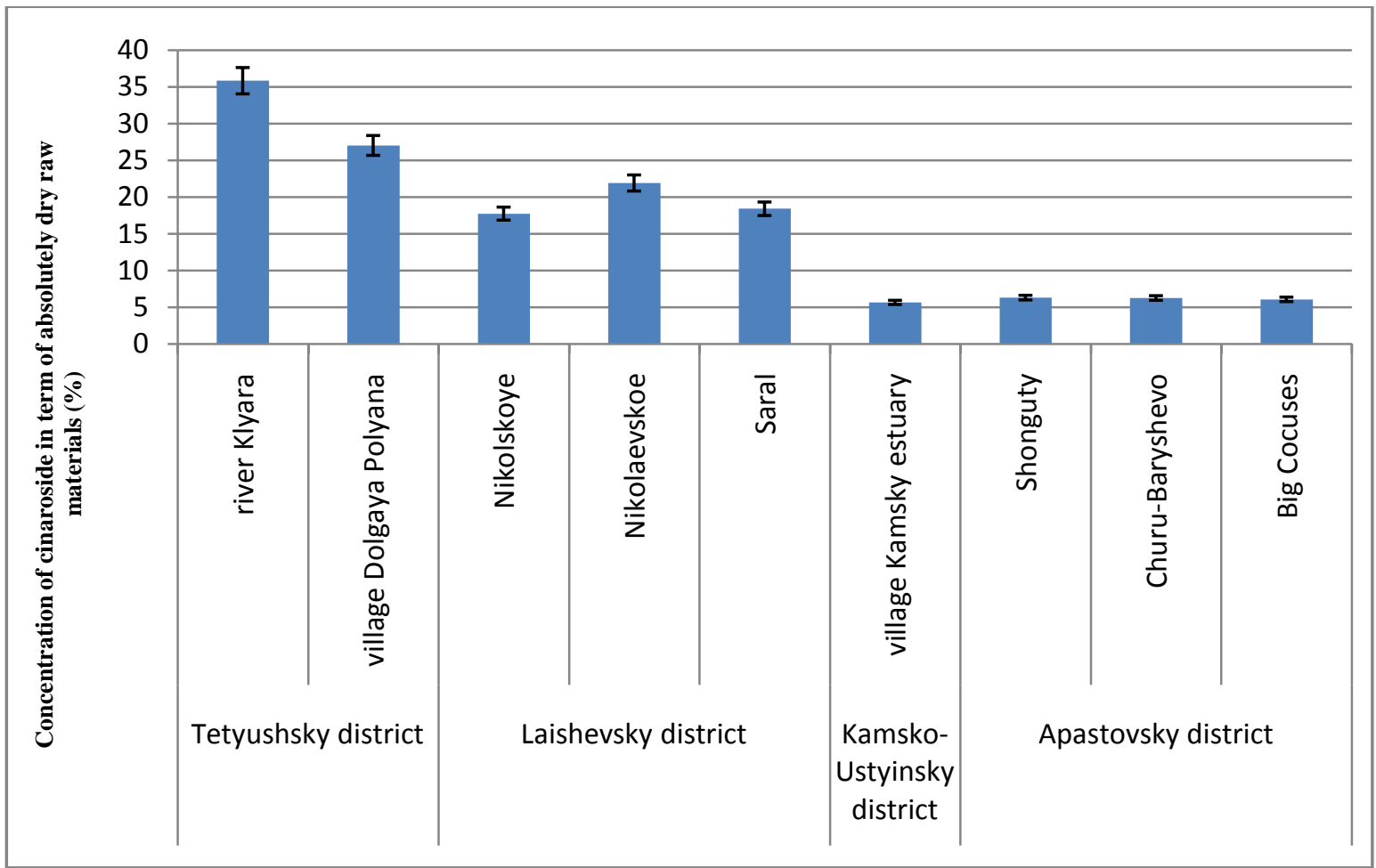

Figure 3 Amount of cinaroside in clover plants of the meadow zone of the broad-leaved forests of the Republic of Tatarstan

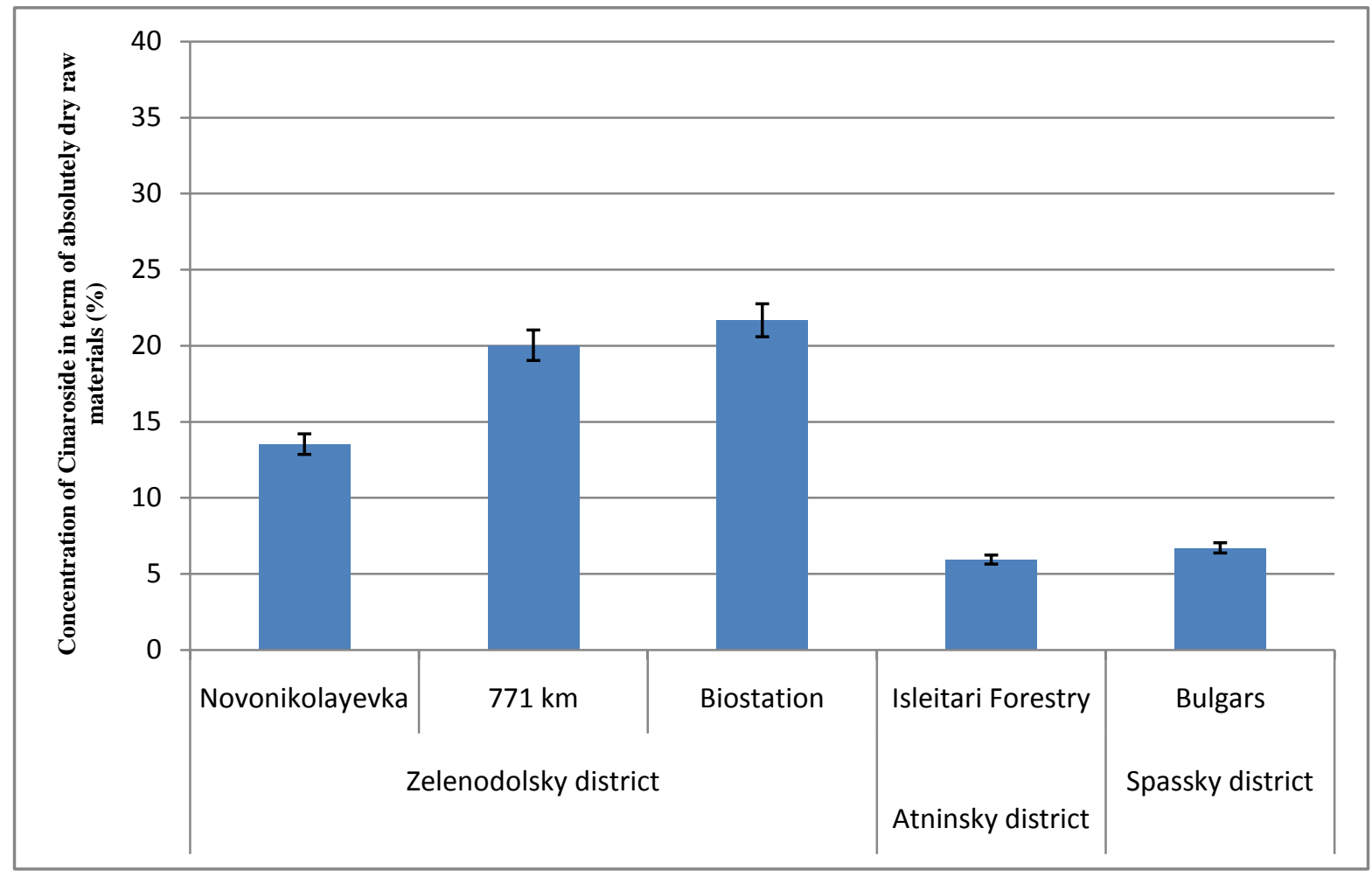

Figure 4 Cinaroside content in red clover plants samples collected from the meadow zone of the broad-leaved forests of the Republic of Tatarstan

Journal of Experimental Biology and Agricultural Sciences http://www.jebas.org 


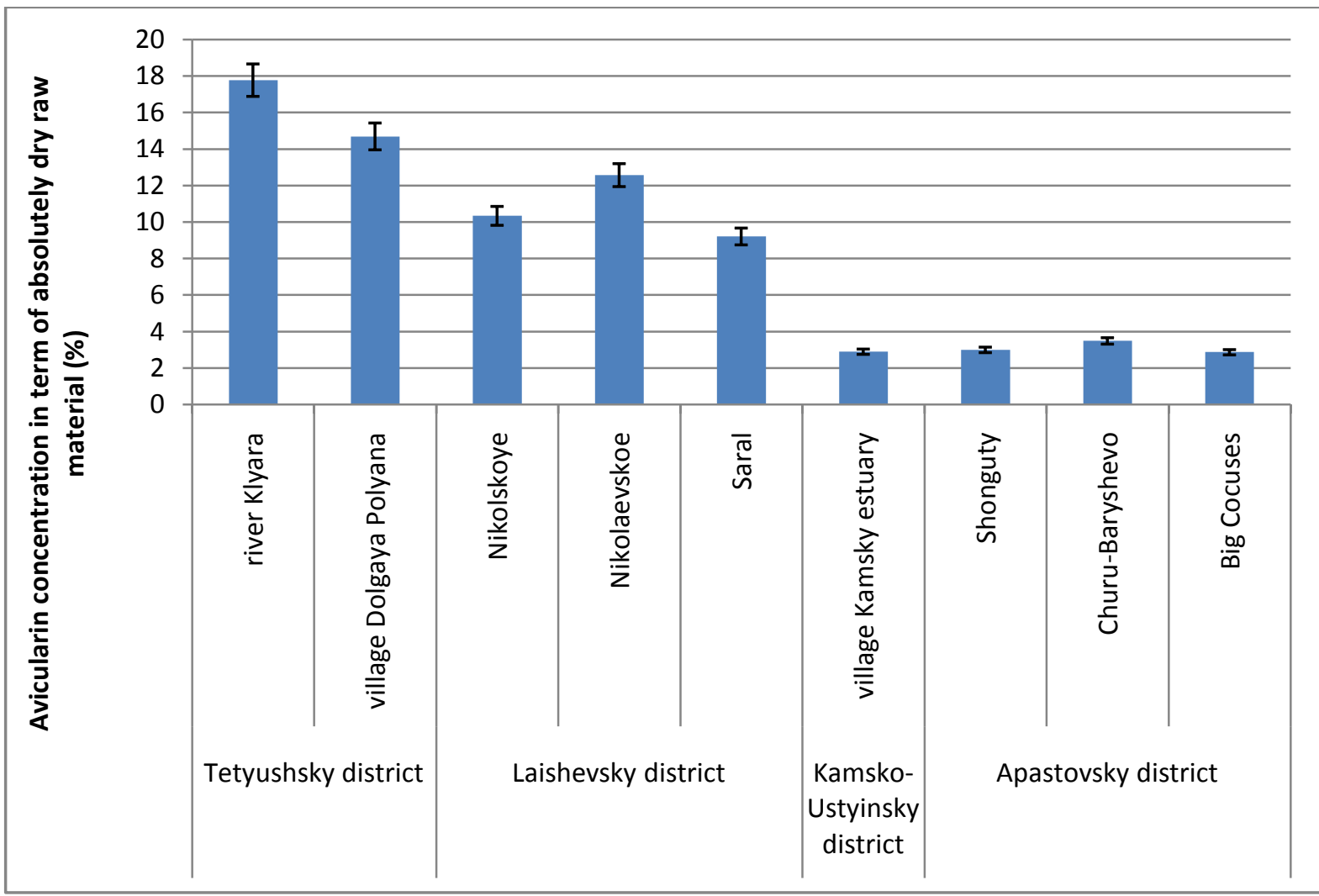

Figure 5The content avicularin in clover plants of the meadow zone of the broad-leaved forests of the Republic of Tatarstan

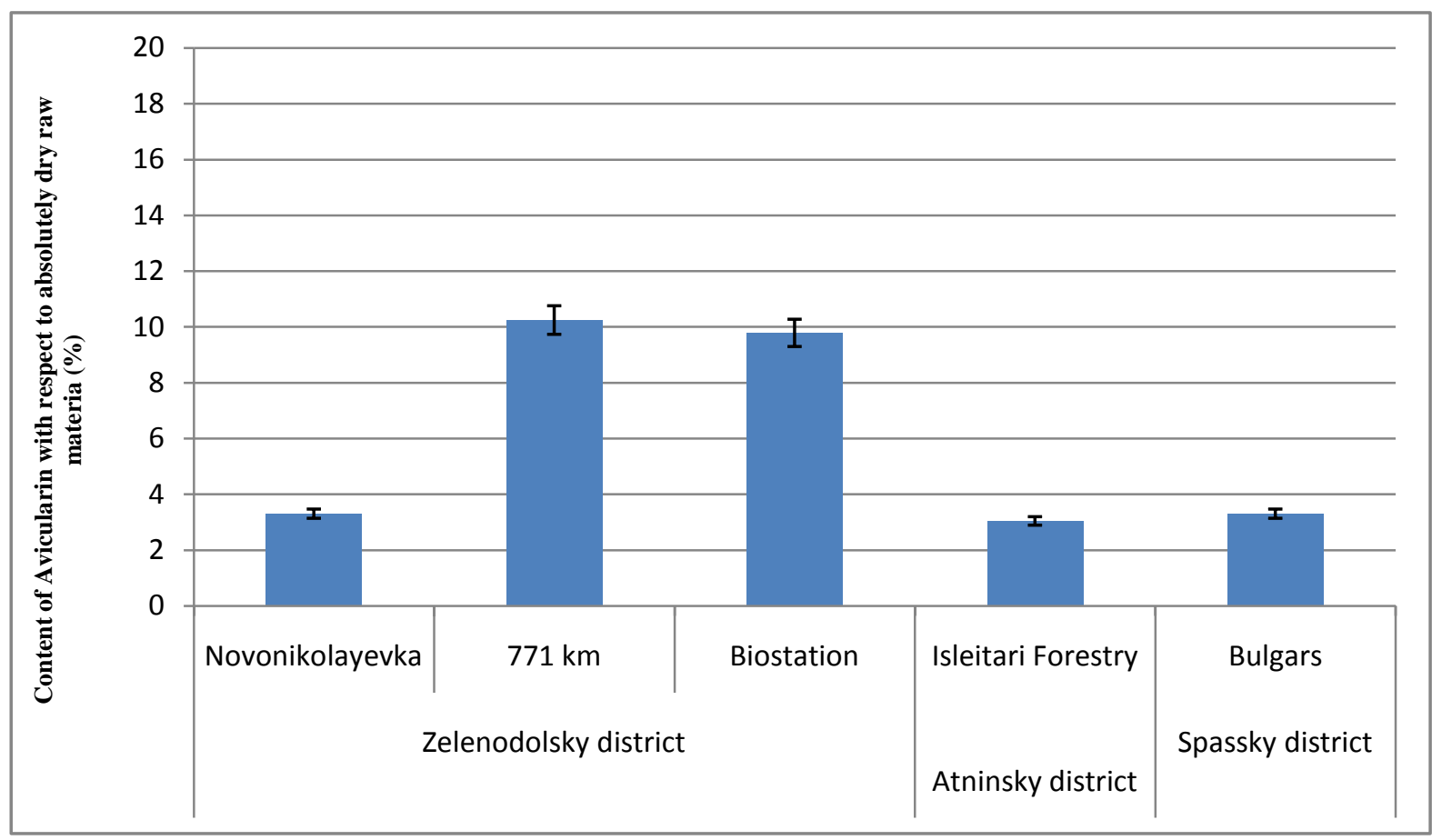

Figure 6 The content of avicularin in meadow red clover plants from different zones of RT growth

Journal of Experimental Biology and Agricultural Sciences http://www.jebas.org 


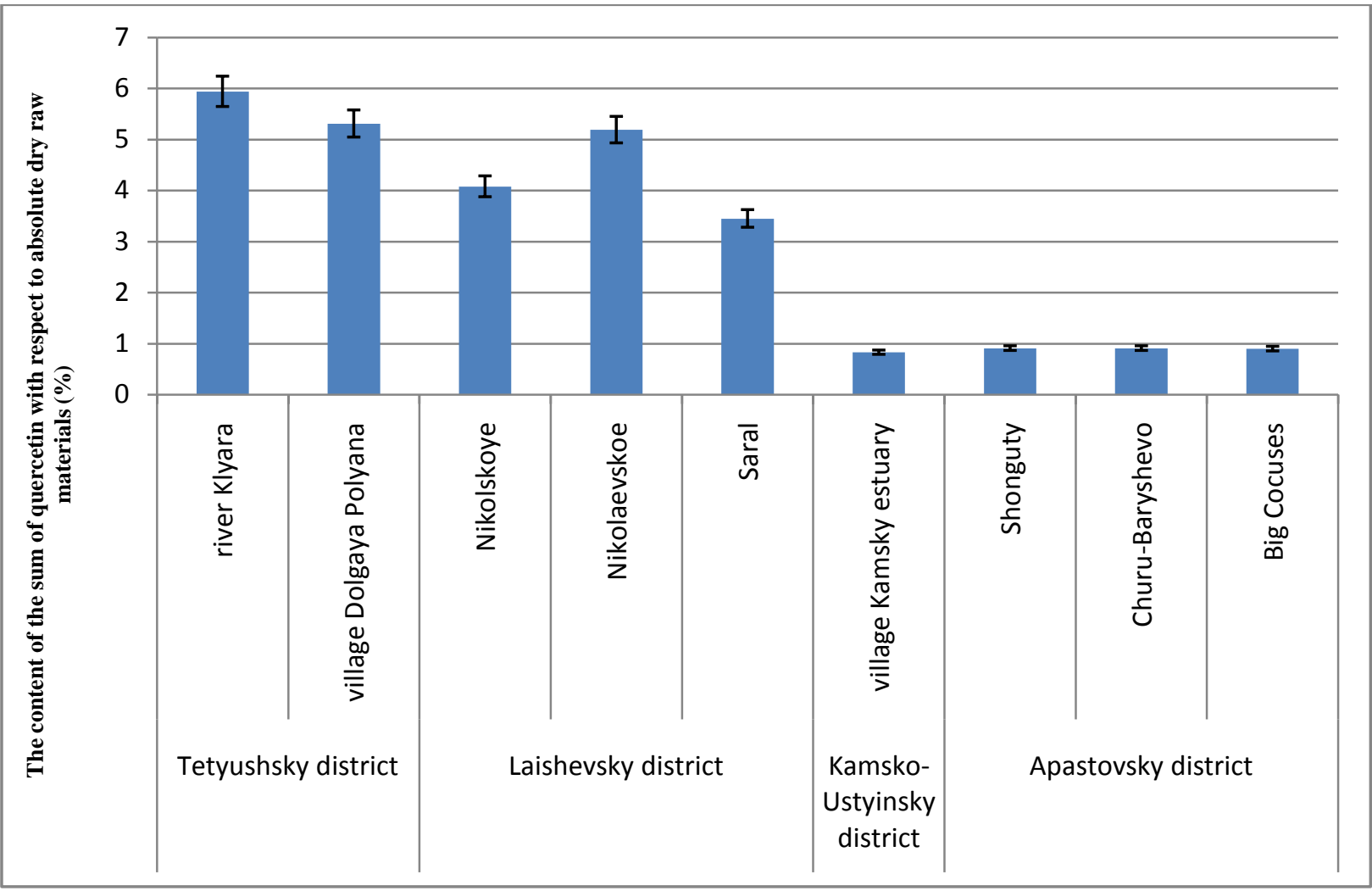

Figure 7 The content of quercetin in red clover plants in the meadow zone of the broad-leaved forests of the Republic of Tatarstan

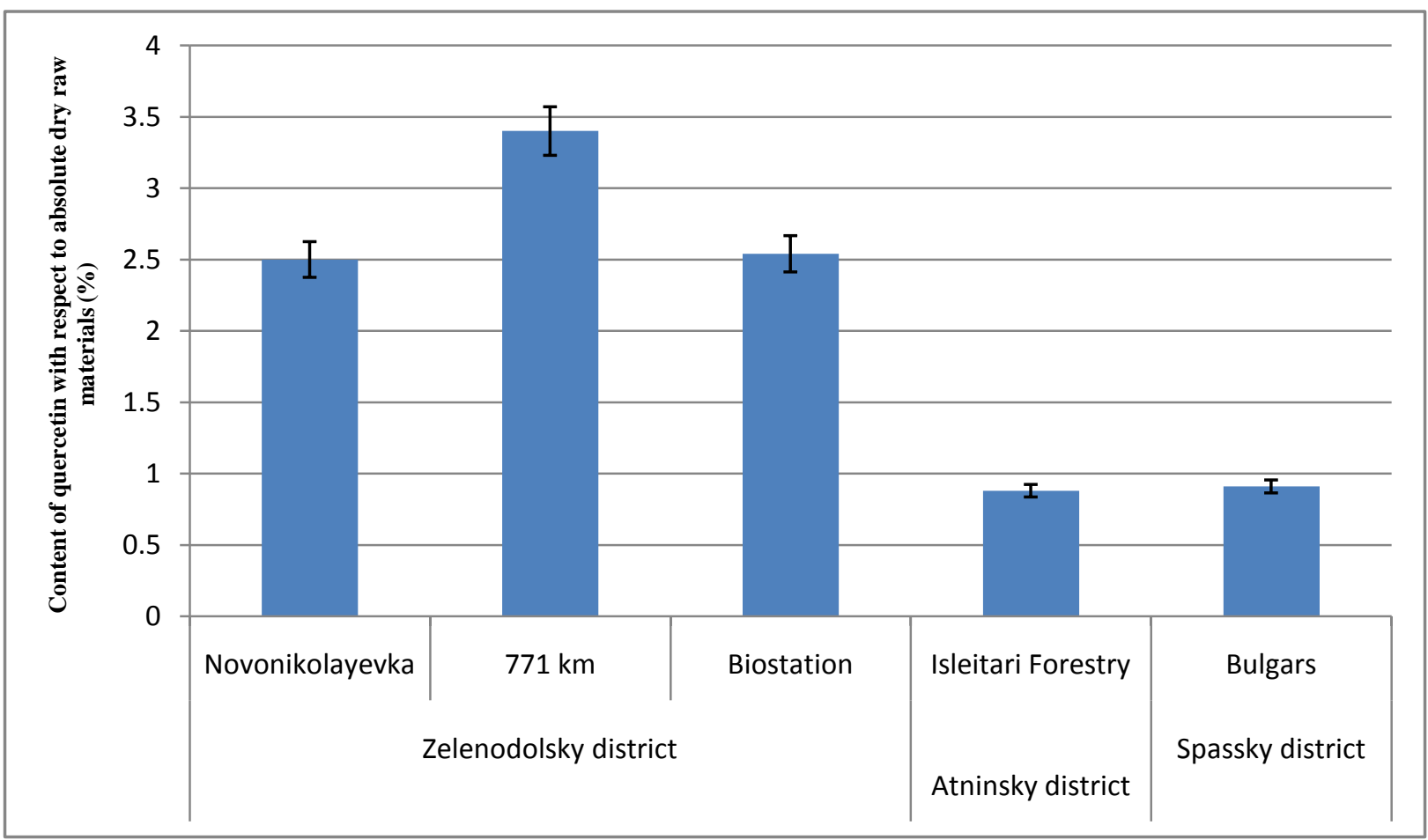

Figure 8 The content of quercetin in red clover plants of the meadow zone of broad-leaved forests of the Republic of Tatarstan

Journal of Experimental Biology and Agricultural Sciences http://www.jebas.org 
Further, like cynaroside, the second highest flavonoids is avicularin and this was also reported from the meadow clover samples collected from the zone of deciduous forests located in Tetyushsky and Laishevsky districts. Further, Clover plants growing near the Klyara river (17.76\%), the village of Dolgaya Polyana (14.7\%), Tetyushsky district, and the village of Nikolaevskoe $(12.56 \%)$ of Laishevsky district deserve special attention (Figure 5).

In the case of Zelenodolsk district, high content of avicularin was reported from the coniferous-deciduous forests located in biostation (9.78\%) and $771 \mathrm{~km}(10.24 \%)$ (Figure 6). The lowest content of avicularin was found in the plant grown in KamskoUst'insky and Apastovsky District of deciduous forests, southern taiga (Atninsky district), and forest-steppe (Spassky district) subzones (Figure $5 \& 6$ ).

Experimental data show that the most noteworthy substance quercetin was found in the red clover samples collected from the deciduous forests of Tetyushsky and Laishevsky districts (Figure 7). The least content of quercetin was observed in the KamskoUst'insky and Apastovsky district of the deciduous forests zone, and the southern taiga (Atninsky district) and forest-steppe subzones (Spassky district) (Figure $7 \& 8$ ).

Syntheses of primary and secondary metabolites are associated with each other and synthesis of these affects the processes of growth and accumulation of plant biomass. Plants from the Tetyushsky district had the highest content of flavonoids that's why these plants had the lowest values of growth parameters as compared to plants from other districts of deciduous forests. As is known, the synthesis and amassing of phenolic compounds gatherings by plants can be expressed in their adaptive response to unfavorable environmental conditions. There are several data on the effect of illumination on the synthesis and accumulation of phenols, depending on the illumination factor.

Water pressure is likewise one of the main environmental factors that can control the plant development and advancement, as well as their biochemical properties. As a rule, water scarcity reduces plant growth and development and leads to an increase in secondary metabolites, including phenolic compounds. Literature describes an increase in phenolic compounds during drought and water deficiency in the soil, which activates the plants' protective response under oxidative stress (Andersen, 2005).

The mineral component of the soil can also serve as a means of stimulating plant growth and affect the content of secondary metabolites. Further, it has been also reported that the degree of nitrogen and phosphorus significantly affects the creation of phenolic mixes and flavonoids specifically. For example, in many plants, the nitrogen level is proportionally correlated with morphological parameters and the level of phenolic compounds (Inderjit \& Mallik, 1997; Heimler et al., 2017; Stumpf et al., 2018). Phosphorus also plays a major role in many enzymatic reactions, photosynthesis, and plant metabolism. It also contributes to the accumulation of flavonoids, tannins, cardiac glycosides in plants. Nevertheless, an increase in the concentration of phosphorus in the soil contributes to the inhibition of the production of flavones by plants. Treatment of the soil with an NPK solution significantly reduces the level of phenolic compounds, while a decrease in the content of phosphorus and potassium in the soil negatively affects phenolic metabolism (Seneviratne et al., 2003).

In the present study, one of the decisive factors, in addition to the geographical position of the population, seems to be the illumination. In the same geographic zone of broadleaf forests, the content of phenolic compounds varied significantly in different districts. At the same time, the habitats of clover plants with a higher level of phenolic compounds, Tetyushsky and Laishevsky districts, were characterized by high illumination, in comparison with Kamsko-Ustinsky, where the illumination was about $50 \%$ of the total, even though they are located in the same geographical zone. In the Apastovsky district, the illumination is above 50\% and plants from this district had intermediate values of phenolic compounds (between Tetyushsky, Laishevsky, and KamskoUstinsky districts).

The second factor that also affects the content of phenolic compounds is the nitrogen content in the soil. The soils of the Kamsko-Ustinsky district have a high nitrogen content and their plants contain the least phenolic compounds, in comparison with plants from other districts of the zone of deciduous forests. Thus, both the content of individual flavonoids and their total content was higher in red clover plants in the zone of deciduous forests of the Tetyushsky and Laishevsky districts.

\section{Conclusion}

The content of biologically active compounds in clover is largely due to the geographical location and soil and climatic conditions. The most ideal conditions for the amalgamation of phenolic mixes in plants of Trifolium L. are zones of broadleaved forests. Furthermore, the elements affecting the aggregation of phenolic mixes are the enlightenment and the inventory of soil with nitrogen. The analysis of the results of this phytochemical study of clovers proves this plant to be the source of a whole complex of pharmacologically active compounds, which creates the prerequisites for its more detailed, in-depth study as a full-fledged object of phytotherapeutic methods and directions of the treatment since this species belongs to plant sources of natural medicines. 


\section{Acknowledgments}

The work is performed by the Russian Government Program of Competitive Growth of Kazan Federal University. The paper was distributed with the monetary help of the RFBR and the Government of the Republic of Tatarstan inside the system of the logical venture No.18-44-160015.

\section{Conflict of Interest}

Authors would hereby like to declare that there is no conflict of interests that could possibly arise.

\section{References}

Andersen CP (2005) Source-sink balance and carbon allocation below ground in plants exposed to ozone. New Phytologist 157(2): 213-228.

Bautista I, Boscaiu M, Lidón A, Llinares JV, Lull C, Pilar DM, Mayoral O, Vicente O (2016) Environmentally induced changes in antioxidant phenolic compounds levels in wild plants. Acta $\begin{array}{llll}\text { Physiologiae } & \text { Plantarum } & \text { 38, } & 9\end{array}$ https://doi.org/10.1007/s11738-015-2025-2.

Havsteen B (1983) Flavonoids, a class of natural products of high pharmacological potency. Biochemical Pharmacology 32(7):1141-1148.

Heimler D, Romani A, Ieri F (2017) Plant polyphenol content, soil fertilization and agricultural management: a review. European Food Research and Technology 243:1107-1115. DOI: https://doi.org/10.1007/s00217-016-2826-6.

Hertog MGL, Kromhout D, Aravanis C, et al. (1995) Flavonoid intake and long-term risk of coronary heart disease and cancer in the Seven Countries Study. Archives of Internal Medicine. 155(4):1184-1195.

Hoekstra NJ, De Deyn GB, Xu Y, Prinsen R, Van Eekeren N (2017) Red clover varieties of Mattenklee type have higher production, protein yield and persistence than Ackerklee types in grass-clover mixtures. Grass and Forage Science 73(2): 297-308. https://doi.org/10.1111/gfs.12307.

Inderjit, Mallik AU (1997) Effect of phenolic compounds on selected soil properties. Forest Ecology and Management 92 (1-3) : 11-18. DOI: https://doi.org/10.1016/S0378-1127(96)03957-6.

Jaakola L, Hohtola A (2010) Effect of latitude on flavonoid biosynthesis in plants. Plant, cell \& Environment 33(8):1239-47.
Klyshev LK, Bandyukova VA, Alyukina LS (1978) Plant flavonoids.Distribution, physico-chemical properties and investigation methods. In: Flavonoidy rastenii. Rasprostranenie, fiziko-khimicheskie svoistva, metody issledovaniya, Pp.220.

Kolodziejczyk-Czepas J (2016) Trifolium species - the latest findings on chemical profile, ethnomedicinal use and pharmacological properties. Journal of Pharmacy and Pharmacology 68(7): 845-861.

Koricheva JU, Barton KE (2012) Temporal changes in plant secondary metabolite production: patterns, causes and consequences. The ecology of plant secondary metabolites. Cambridge University Press, Cambridge 19:34-55.

Król A, Amarowicz R, Weidner S (2014) Changes in the composition of phenolic compounds and antioxidant properties of grapevine roots and leaves (Vitis vinifera L.) under continuous of long-term drought stress. Acta Physiologiae Plantarum 36: 14911499 (2014). https://doi.org/10.1007/s11738-014-1526-8

Seneviratne G, Jayasinghearachchi HS (2003) Mycelial colonization by bradyrhizobia and azorhizobia. Journal of Biosciences 28(2):243-247.

Shankar SRM, Rajendraparasad G, Karthik N, Rajendran R, Mahendran VS (2009) Allelopathic effects of phenolics and terpenoids extracted from Gimelina arborea on germination of Black gram (Vigna mungo) and Green gram (Vigna radiata). Allelopathy Journal 23(2): 323-332.

Sibgatullina GV (2011) Methods for determining the redox status of cultivated plant cells. In: Sibgatullina GV, Khaertdinova LR, Gumerova EA, Akulov AN, Kostiukova IuA, Nikonorova NA, Rumiantseva NI, a study guide Kazan: Kazan (Volga Region) Federal University,. - Pp.61 .

Stumpf B, Yan F, Honermeier B (2018) Influence of nitrogen fertilization on yield and phenolic compounds in wheat grains (Triticum aestivum L. ssp. aestivum). Journal of Plant Nutrition and Soil Science 182(1): 111-118. DOI: https://doi.org/10.1002/jpln.201800342.

Wang Q, Eneji AE, Kong X, Wang K, Dong H (2015) Salt stress effects on secondary metabolites of cotton in relation to gene expression responsible for aphid development. PloS one10(6):e0129541. 